\title{
HSP-70-Mediated Hyperbaric Oxygen Reduces Brain and Pulmonary Edema and Cognitive Deficits in Rats in a Simulated High-Altitude Exposure
}

\author{
Hsing-Hsien Wu, ${ }^{1,2}$ Ko-Chi Niu, ${ }^{3}$ Cheng-Hsien Lin $\mathbb{D}^{4},{ }^{4}$ Hung-Jung Lin $\mathbb{D},{ }^{5,6}$ \\ Ching-Ping Chang $\mathbb{D}^{7}$ and Chia-Ti Wang $\mathbb{D}^{5}$ \\ ${ }^{1}$ Division of Thoracic Surgery, Department of Surgery, Tainan Municipal Hospital (Managed by Show Chwan Medical Care Corporation), \\ Tainan, Taiwan \\ ${ }^{2}$ Department of Nursing, Chung Hwa University of Medical Technology, Tainan, Taiwan \\ ${ }^{3}$ Department of Hyperbaric Oxygen, Chi Mei Medical Center, Tainan, Taiwan \\ ${ }^{4}$ Department of Medicine, Mackay Medical College, New Taipei, Taiwan \\ ${ }^{5}$ Department of Emergency Medicine, Chi Mei Medical Center, Tainan, Taiwan \\ ${ }^{6}$ Department of Biotechnology, Southern Taiwan University of Science and Technology, Tainan, Taiwan \\ ${ }^{7}$ Department of Medical Research, Chi Mei Medical Center, Tainan, Taiwan
}

Correspondence should be addressed to Ching-Ping Chang; jessica.cpchang@gmail.com and Chia-Ti Wang; tigerwang900708@gmail.com

Received 27 April 2018; Revised 27 August 2018; Accepted 16 September 2018; Published 1 November 2018

Academic Editor: Shigehiko Ogoh

Copyright (C) 2018 Hsing-Hsien Wu et al. This is an open access article distributed under the Creative Commons Attribution License, which permits unrestricted use, distribution, and reproduction in any medium, provided the original work is properly cited.

High-mountain sickness is characterized by brain and pulmonary edema and cognitive deficits. The definition can be fulfilled by a rat model of high-altitude exposure (HAE) used in the present study. This study aimed to investigate the protective effect of hyperbaric oxygen therapy $\left(\mathrm{HBO}_{2} \mathrm{~T}\right)$ and to determine the underlying mechanisms. Rats were subjected to an $\mathrm{HAE}$ (9.7\% $\mathrm{O}_{2}$ at 0.47 absolute atmosphere of $6,000 \mathrm{~m}$ for 3 days). Immediately after termination of HAE, rats were treated with $\mathrm{HBO}_{2} \mathrm{~T}\left(100 \% \mathrm{O}_{2}\right.$ at 2.0 absolute atmosphere for 1 hour per day for 5 consecutive days) or non- $\mathrm{HBO}_{2} \mathrm{~T}\left(21 \% \mathrm{O}_{2}\right.$ at 1.0 absolute atmosphere for 1 hour per day for 5 consecutive days). As compared to non-HAE+non- $\mathrm{HBO}_{2} \mathrm{~T}$ controls, the $\mathrm{HAE}+$ non- $\mathrm{HBO}_{2} \mathrm{~T}$ rats exhibited brain edema and resulted in cognitive deficits, reduced food and water consumption, body weight loss, increased cerebral inflammation and oxidative stress, and pulmonary edema. $\mathrm{HBO}_{2} \mathrm{~T}$ increased expression of both hippocampus and lung heat shock protein (HSP-70) and also reversed the HAE-induced brain and pulmonary edema, cognitive deficits, reduced food and water consumption, body weight loss, and brain inflammation and oxidative stress. Decreasing the overexpression of HSP-70 in both hippocampus and lung tissues with HSP-70 antibodies significantly attenuated the beneficial effects exerted by $\mathrm{HBO}_{2} \mathrm{~T}$ in HAE rats. Our data provide in vivo evidence that $\mathrm{HBO}_{2} \mathrm{~T}$ works on a remodeling of brain/lung to exert a protective effect against simulated high-mountain sickness via enhancing HSP-70 expression in HAE rats.

\section{Introduction}

High-mountain sickness characterized by cerebral and pulmonary edema and cognitive dysfunction that occurs after high-altitude exposure (HAE) is commonly seen among climbers and tourists $[1,2]$. Indeed, the high-mountain sickness syndromes displayed by patients can be reproduced by the rats exposed to $\operatorname{HAE}[3,4]$.

Hyperbaric oxygen $\left(\mathrm{HBO}_{2}\right)$ preconditioning has been promoted as a promising method for preventing the occurrence of cerebral and pulmonary edema in rats exposed to a simulated HAE $[4,5]$. However, it is not known whether 


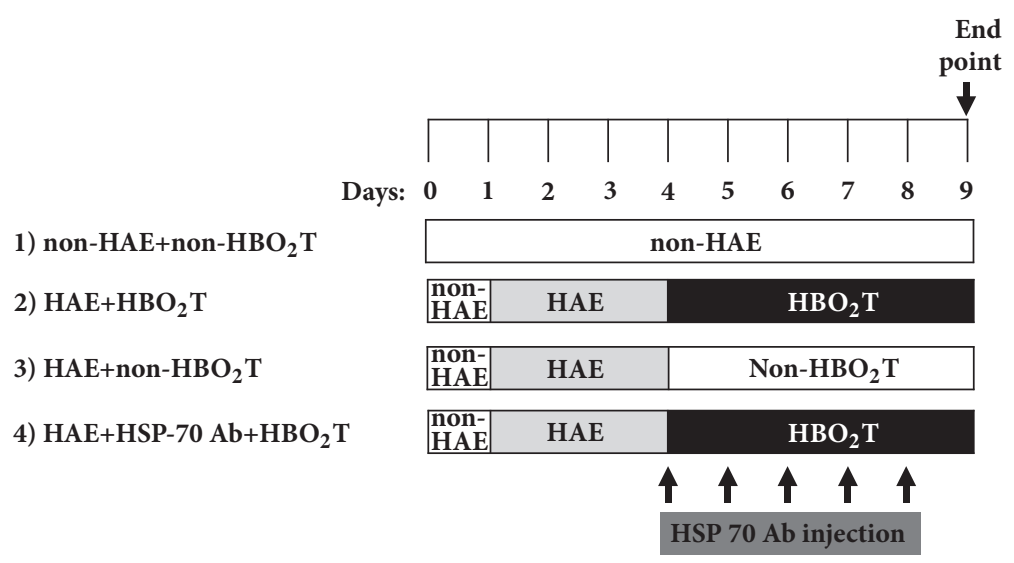

Figure 1: Experimental design: HAE: $9.8 \% \mathrm{O}_{2}$ at 0.47 ATA; non-HAE: $21 \% \mathrm{O}_{2}$ at 1.0 ATA; $\mathrm{HBO}_{2} \mathrm{~T}: 100 \% \mathrm{O}_{2}$ at 2.0 ATA $1 \mathrm{~h}$ per day; and non- $\mathrm{HBO}_{2} \mathrm{~T}: 21 \% \mathrm{O}_{2}$ at 1.0 ATA.

$\mathrm{HBO}_{2}$ adopted after a simulated HAE is still able to ameliorate the occurrence of cerebral and pulmonary edema and its underlying mechanisms.

It is well accepted that heat shocks protein- (HSP-) 70 induction by several physiological or pathological stress protects against subsequent damage by increasing the tolerance of affected cells [6,7]. Full protection may not be observed if HSP-70 expression is at reduced levels or if the insult is severe [6,7]. Although a recent study [8] has demonstrated that decreasing or increasing HSP-70 exacerbates or attenuates heat-induced cell death, respectively, in rat hypothalamic cells, a recent report indicates that HSP-70 is a novel biomarker reflecting the severity of disease conditions [9]. Therefore, further studies are needed to establish the role of HSP-70 activity in the pathogenesis of high-mountain sickness.

To date, no studies have explored the potential of hyperbaric oxygen therapy $\left(\mathrm{HBO}_{2} \mathrm{~T}\right)$ to protect animals in the setting of high-mountain sickness characterized by cerebral and pulmonary edema with its complications. In this study, we attempt to investigate the hypothesis that HBOT can induce protective properties in an animal model of highmountain sickness via stimulating HSP-70 activity.

\section{Materials and Methods}

2.1. Ethical Approval of the Study Protocol. All the experiments were approved by the ethical guidelines laid down by The Institutional Animal Care and Use Committee at Chi Mei Medical Center (IACUC approved number: 101122406-1). All protocols were designed to minimize pain and discomfort during both the injury procedure and recovery.

2.2. Animals and Experimental Groups. Adult male Wistar rats (280-300 $\mathrm{g}$ at the beginning of the study) were maintained at $22 \pm 1.0^{\circ} \mathrm{C}$ with $12: 12 \mathrm{~h}$ light to dark cycle and given food and water ad libitum. One hundred and twenty rats were randomly assigned to one of the following 4 groups: (i) non-HAE+non- $\mathrm{HBO}_{2} \mathrm{~T}$ group: the rat is exposed to normobaric air (non- $\mathrm{HBO}_{2} \mathrm{~T}: 21 \%$ at 1.0 ATA) throughout the entire experiments; (ii) $\mathrm{HAE}+$ non- $\mathrm{HBO}_{2} \mathrm{~T}$ group: immediately after $\mathrm{HAE}$, the rat is treated with normobaric air; (iii) $\mathrm{HAE}+\mathrm{HBO}_{2} \mathrm{~T}$ group: immediately after high-altitude exposure (HAE: $9.8 \% \mathrm{O}_{2}$ at 0.47 ATA for 3 days), the rat is treated with one regimen of $\mathrm{HBO}_{2} \mathrm{~T}\left(100 \% \mathrm{O}_{2}\right.$ at 2.0 ATA $1 \mathrm{~h}$ per day for 5 consecutive days); and (iv) $\mathrm{HAE}+\mathrm{HSP}-70 \mathrm{Ab}+\mathrm{HBO}_{2} \mathrm{~T}$ group: the rat is treated with one regimen of both HSP$70 \mathrm{Ab} \mathrm{HBO}_{2} \mathrm{~T}$ immediately after $\mathrm{HAE}$ and once daily for 5 consecutive days as summarized in Figure 1. Figure 1 illustrates the timeline of experimental procedures. On Day 9, after the last $\mathrm{HBO}_{2} \mathrm{~T}$, the rats were deeply anaesthetized with sodium pentobarbital $(65 \mathrm{mg} / \mathrm{kg}$, intraperitoneally; SigmaAldrich, St. Louis, MO, USA) and both the blood and brain samples were collected for verification.

2.3. A Simulated High-Mountain Sickness Model. There is no precise method for modelling high-mountain sickness in animals [10]. In the present study, we modified our previous study [9] by exposing rats to a simulated $\operatorname{HAE}(9.7 \% \mathrm{O} 2$ at 0.47 ATA) of $6,000 \mathrm{~m}$ in a hypobaric chamber for 3 days to induce a simulated high-mountain sickness. In accordance with the study of Patir et al. [11], we evaluated tissue water content and vascular leakage, two critical indicators of cerebral and lung edema.

2.4. Hippocampal and Lung Expression Levels of HSP-70 and Inhibition of HSP-70 Activity. Anaesthetized rats were killed by decapitation at the end of the experiment, and their brains and lungs were immediately removed. The hippocampus was separated from the brain. After carefully rinsing in cooled phosphate-buffered saline, the tissues were homogenized on ice in a RIPA (Radio Immuno Precipitation Assay) lysis buffer (Bio-Rad Laboratories, Inc., Hercules, CA, USA). The hippocampus and lung samples stored at $-80^{\circ} \mathrm{C}$ were used for HSP-70 protein quantification using western blot. Protein content was measured by BCA assay (Thermo Fisher Scientific, Waltham, MA, USA) according to the standard protocols. The methods used for determination of hippocampus and lung expression of HSP-70 (1:1000; Enzo Life Sciences, Farmingdale, NY, USA) and $\beta$-actin 
(1:4000; Santa Cruz Biotechnology, Santa Cruz, CA, USA) were modified from our previous study [12]. Both HSP-70 and actin expressions of both hippocampus and lung were semiquantified using a gel densitometry scanning program. A neutralizing polyclonal rabbit anti-rat HSP-70 polyclonal antibody $(25 \mu \mathrm{g} / \mathrm{kg}$ of body weight; ADI-SPA-812-F, Enzo Life Sciences, Inc., Farmingdale, NY, USA) dissolved in nonpyrogenic sterile saline was injected intraperitoneally immediately and once daily for 4 consecutive days after termination of an HAE.

2.5. Passive Avoidance Learning Test and Y-Maze Test. We performed a passive avoidance learning trail for each rat at 5 days after each rat had recovered from an HAE, as previously described [13]. A single, inescapable scrambled electric shock was delivered for 3 seconds after the rat entered the dark chamber. The latency to entering the dark compartment from the light compartment was defined as the testing latency. Each rat was scored on Day 5 after HAE.

For determining spatial memory function, the Y-maze test was performed at 5 days after HAE in rats as previously described [14]. For each animal during one Y-maze testing session, both the latency to enter the correct arm (time of reaction) and the number of wrong entries (error number) were measured.

2.6. Hippocampal Levels of 2,3-dihydroxybenzoic Acid (2,3DHBA) and Nitric Oxide Metabolites (NOx). Hydroxyl radicals (e.g., 2,3-DHBA) were measured using a modified procedure based on the hydroxylation of sodium salicylate by hydroxyl radicals, leading to the formation of 2,3-DHBA [15]. The NOx concentrations in the dialysates obtained from the implanted microdialysis probe in the brain were measured with a NOx analysis system (ENO-20; Eicom, Kyoto, Japan) [16].

\subsection{Hippocampal Levels of Prooxidant and Antioxidant} Enzymes. Hippocampal levels of prooxidant enzymes (e.g., malondialdehyde and oxidized glutathione) and antioxidant enzymes (e.g., reduced glutathione, glutathione peroxidase, glutathione reductase, and superoxide dismutase) were determined. Lipid peroxidation was measured by determining the brain levels of malondialdehyde (MOD) with 2thiobarbituric acid [17].

The reduced glutathione (GSH; an antioxidant enzyme) and the oxidized glutathione (GSSG; a prooxidant enzyme) were determined as previously described $[18,19]$. The glutathione peroxidase (GPx; an antioxidant enzyme), glutathione reductase (GR; an antioxidant enzyme), and superoxide dismutase (SOD; an antioxidant enzyme) in the brain tissues were determined accordingly.

2.8. Hippocampal Levels of Proinflammatory Cytokines. The hippocampal levels of inflammatory cytokines (TNF- $\alpha$, IL-10, and IL-1 $\beta$ ) were quantified using enzyme-linked immunosorbent assay (ELISA) kits (catalogue nos. KRC3011C, BMS629TEN, and ERIL1B, all from Thermo Fisher Scientific Inc., Waltham, MA, USA) specific for rats according to the manufacturers' instructions. The cytokine levels in the brain samples were expressed as pictograms of antigen per milligram of protein.

2.9. Measurement of Brain and Lung Water Content. Brain water content (brain edema) or lung water content (pulmonary edema) was evaluated via the wet weight/ dry weight ration method, as previously reported [20-23]. Rats were euthanized and thoroughly exsanguinated before their brains and lungs were excised en bloc. Both brain and lung were blotdried and placed in preweighed trays made of aluminium foil separately. The wet weight of brain tissue or lung tissue was registered immediately on an electronic balance to an accuracy of $0.1 \mathrm{mg}$. The tray containing brain tissue or lung tissue was then baked in an oven at $100^{\circ} \mathrm{C}$ for $24 \mathrm{~h}$ until a constant weight was achieved. Brain and lung water content were calculated as percentage of [(wet weight-dry weight)/ wet weight] $\times 100$.

2.10. Evans Blue Extravasation Assay. Evans blue extravasation assays were conducted in accordance with the methods of Lin et al. [24]. Animals received an intravenous injection of $0.25 \mathrm{ml}$ Evans Blue dye (4\%), 3 hours prior to sacrifice. Following that, deeply anesthetized animals were transcardially perfused with ice-cold PBS $(100 \mathrm{~mL})$ and both lung and brain were removed, snap-frozen in liquid nitrogen, and stored at $-80^{\circ} \mathrm{C}$. The quantity of extravasated Evans Blue dye was detected by spectrophotometer (Thermo Fischer Scientific Inc., Waltham, MA, USA) at $610 \mathrm{~nm}$ and quantified according to a standard curve. The results are presented as $\mu \mathrm{g}$ of Evans Blue dye per $g$ of tissue.

2.11. Measurement of Proinflammatory Cytokines in Bronchoalveolar (BAL) Fluid. The concentrations of interleukin$1 \beta$ (IL- $1 \beta)$, IL-6, and tumor necrosis factor- $\alpha$ (TNF- $\alpha$ ) in BAL fluid were determined using ELISA (Thermo Fisher Scientific Inc., Waltham, MA, USA) according to the manufacturer's instruction. Optical densities were read on a plate reader set at $450 \mathrm{~nm}$ for IL-6, IL-1 $\beta$, and TNF- $\alpha$. The levels of these cytokines in the samples were calculated from the standard curve multiplied by the dilution factor and were expressed as pictogram per millimetre.

2.12. Statistical Analysis. Results are expressed as the mean \pm SD. Behavioural results are tested for normality (D'Agostino\& Pearson omnibus normality test) and skewness using Graph Pal Prism 7.01 (Graph Pad Software, San Diego, CA, USA). The statistical analysis was carried out using repeated measure ANOVA and nonparametric KruskalWallis and Mann-Whitney $U$ tests. A statistical $P$ value less than 0.05 was considered significant.

\section{Results}

3.1. $\mathrm{HBO}_{2}$ T Attenuated Body Weight Loss and Reduced Water and Food Intake Consumption in HAE Rats. During 5 days after HAE, all the values of body weight, food intake, and 
TABLE 1: Percentage change of oxidative stress markers like 2,3-DHBA, nitric oxide metabolite (NOx), and lipid peroxidation, glutathione system like reduced GSH, GSSG, and ratio of reduced/oxidized glutathione (GSH/GSSG), and antioxidant enzymes like GPx, GR, and SOD levels in the hippocampus of rat brain of all four groups.

\begin{tabular}{|c|c|c|c|c|}
\hline Parameters & $\begin{array}{c}\text { non-HAE+ } \\
\text { non- } \mathrm{HBO}_{2} \mathrm{~T}\end{array}$ & $\begin{array}{c}\text { HAE+ } \\
\text { non-HBO }{ }_{2} \mathrm{~T}\end{array}$ & $\begin{array}{l}\mathrm{HAE}+ \\
\mathrm{HBO}_{2} \mathrm{~T}\end{array}$ & $\begin{array}{c}\mathrm{HAE}+\mathrm{HSP}-70 \mathrm{Ab}+ \\
\mathrm{HBO}_{2} \mathrm{~T}\end{array}$ \\
\hline 2,3-DHBA & $100 \pm 9$ & $166 \pm 14 *$ & $118 \pm 10^{+}$ & $170 \pm 16^{\#}$ \\
\hline $\mathrm{NOx}$ & $101 \pm 8$ & $568 \pm 17 *$ & $212 \pm 11^{+}$ & $574 \pm 21^{\#}$ \\
\hline $\begin{array}{l}\text { Lipid } \\
\text { peroxidation } \\
(\mathrm{MOD})\end{array}$ & $100 \pm 7$ & $297 \pm 24 *$ & $173 \pm 16^{+}$ & $303 \pm 26^{\#}$ \\
\hline $\mathrm{GSH}$ & $99 \pm 6$ & $75 \pm 9 *$ & $92 \pm 11^{+}$ & $72 \pm 8^{\#}$ \\
\hline GSSG & $101 \pm 7$ & $128 \pm 11 *$ & $90 \pm 6^{+}$ & $102 \pm 9^{\#}$ \\
\hline GSH/GSSG & $100 \pm 6$ & $65 \pm 5 *$ & $86 \pm 7^{+}$ & $64 \pm 4^{\#}$ \\
\hline SOD & $100 \pm 5$ & $70 \pm 4 *$ & $85 \pm 5^{+}$ & $68 \pm 6^{\#}$ \\
\hline GPx & $100 \pm 4$ & $79 \pm 3 *$ & $93 \pm 4^{+}$ & $77 \pm 3^{\#}$ \\
\hline GR & $101 \pm 3$ & $47 \pm 4 *$ & $70 \pm 5^{+}$ & $46 \pm 6^{\#}$ \\
\hline
\end{tabular}

Data are mean $\pm \mathrm{SD}$ of 10 rats per group. $* P<0.05$ for $\mathrm{HAE}+$ non- $\mathrm{HBO}_{2} \mathrm{~T}$ group versus non-HAE+non- $\mathrm{HBO}_{2} \mathrm{~T}$ group; ${ }^{+} P<0.05$ for $\mathrm{HAE}+\mathrm{HBO}{ }_{2} \mathrm{~T}$ group versus $\mathrm{HAE}+$ non $-\mathrm{HBO}_{2} \mathrm{~T}$ group; and ${ }^{\#} P<0.05$ for $\mathrm{HAE}+\mathrm{HSP} 70 \mathrm{Ab}+\mathrm{HBO}_{2} \mathrm{~T}$ group versus $\mathrm{HAE}+\mathrm{HBO}_{2} \mathrm{~T}$ group. See Figure 1 legend for group abbreviations.

water intake in the $\mathrm{HAE}+$ non- $\mathrm{HBO}_{2} \mathrm{~T}$ group were significantly lower than those of the non-HAE+non- $\mathrm{HBO}_{2} \mathrm{~T}$ group (Figure 2). However, as compared to those of the HAE+non$\mathrm{HBO}_{2} \mathrm{~T}$ group of rats, the $\mathrm{HAE}+\mathrm{HBO}_{2} \mathrm{~T}$ group rats had significantly higher values of body weight, food intake, and water intake (Figure 2). The beneficial effects of $\mathrm{HBO}_{2} \mathrm{~T}$ were significantly attenuated by HSP-70 Ab treatment (Figure 2).

\section{2. $\mathrm{HBO}_{2} \mathrm{~T}$ Increased Hippocampal and Lung HSP-70} Relative Expression in HAE Rats. Western blotting analysis revealed that $\mathrm{HAE}+\mathrm{HBO}_{2} \mathrm{~T}$ group rats had a significantly higher hippocampal and lung expression of HSP-70 than $\mathrm{HAE}+$ non- $\mathrm{HBO}_{2} \mathrm{~T}$ group rats $(\mathrm{p}<0.05$; Figure 3$)$. In contrast, the HAE+HSP-70 $\mathrm{Ab}+\mathrm{HBO}_{2} \mathrm{~T}$ group had significantly lower levels of both hippocampal and lung expression of HSP-70 $(\mathrm{p}<0.05$; Figure 3).

3.3. $\mathrm{HBO}_{2}$ T Attenuated Cognitive Deficits in HAE Rats. The passive avoidance learning tests show both the preshock latency (acquisition time) and $24 \mathrm{~h}$ postshock latency (retention time) for all groups in passive avoidance learning test (Figure 4(a)). No between-group differences were found for acquisition time $(P>0.05)$ suggesting short-time memory 1.5 hour after test was unaffected by HAE. However, the $\mathrm{HAE}+$ non- $\mathrm{HBO}_{2} \mathrm{~T}$ group rats had significantly shorter retention time than the non-HAE group of rats $(\mathrm{P}<0.05)$. Compared to the HAE+ non- $\mathrm{HBO}_{2} \mathrm{~T}$ group of rats, the $\mathrm{HAE}+\mathrm{HBO}_{2} \mathrm{~T}$ group rats had longer retention time significantly $(P<0.05)$. Inhibition of hippocampal HSP-70 expression with HSP-70 Ab significantly attenuated the beneficial effects of $\mathrm{HBO}_{2} \mathrm{~T}$ in treating $\mathrm{HAE}$-induced complication (Figure 4(a)).

The Y-maze test shows that $\mathrm{HAE}+$ non $-\mathrm{HBO}_{2} \mathrm{~T}$ group rats had a deficit in spatial memory (time of reaction prolonged and error number increased) compared with the non-HAE controls at 5 days after injury (Figures 4(b) and 4(c)). Compared to the $\mathrm{HAE}+$ non- $-\mathrm{HBO}_{2} \mathrm{~T}$ group of rats, the $\mathrm{HAE}+\mathrm{HBO}_{2} \mathrm{~T}$ group rats had better performance in spatial memory (shorter time of reaction and decreased error number) (Figures 4(b) and 4(c)). Again, the beneficial effects of $\mathrm{HBO}_{2} \mathrm{~T}$ in treating HAE-induced cognitive deficits were reduced by HSP-70 Ab (Figures 4(b) and 4(c)).

3.4. $\mathrm{HBO}_{2}$ T Reduced Brain and Lung Edema in HAE Rats. After 3 days of HAE, both the brain (Figure 5(a)) water content and lung water content (Figure 5(b)) were higher because of edema in the $\mathrm{HAE}+$ non- $-\mathrm{HBO}_{2} \mathrm{~T}$ group rats than in the non-HAE+non- $\mathrm{HBO}_{2} \mathrm{~T}$ group rats $(P<0.05$, Figure 5). Brain or lung water content was significantly lower in the $\mathrm{HAE}+\mathrm{HBO}_{2} \mathrm{~T}$ group rats than in the $\mathrm{HAE}+$ non $\mathrm{HBO}_{2} \mathrm{~T}$ group rats $(P<0.05)$. However, the beneficial effects of $\mathrm{HBO}_{2} \mathrm{~T}$ were significantly attenuated in the HAE+HSP$70 \mathrm{Ab}+\mathrm{HBO}_{2} \mathrm{~T}$ group rats (Figure 5 ).

In order to evaluate the brain-blood-barrier permeability and lung-blood barrier permeability, Evans Blue extravasation assays were conducted after HAE. Significantly, the more extravasated dye was found in both brain and lung specimen of $\mathrm{HAE}+$ non- $-\mathrm{HBO}_{2} \mathrm{~T}$ rats $(\mathrm{p}<0.05$, Figure 6$)$, compared to non-HAE+non- $\mathrm{HBO}_{2} \mathrm{~T}$ rats. Treatment with $\mathrm{HBO}_{2} \mathrm{~T}$ preserved brain-blood-barrier and lung-blood barrier integrity, which were shown by significantly reduced dye extravasation compared to HAE+non-HBO2T $(\mathrm{p}<0.05$, Figure 6). However, the beneficial effects of $\mathrm{HBO}_{2} \mathrm{~T}$ in reducing dye extravasation were significantly reversed by $\mathrm{HSP}-70 \mathrm{Ab}$ as shown in $\mathrm{HAE}+\mathrm{HSP}-70 \mathrm{Ab}+\mathrm{HBO}_{2} \mathrm{~T}$ group rats $(\mathrm{p}<0.05$, Figure 6).

3.5. $\mathrm{HBO}_{2}$ T Reversed the Increased Oxidative Stress Markers, Decreased Glutathione System, and Decreased Antioxidant Enzyme in the Brain of HAE Rats. The 2,3-DHBA, NOx, and lipid peroxidation levels in the brain of the HAE+non$\mathrm{HBO}_{2} \mathrm{~T}$ group rats were significantly higher after 3 days of $\mathrm{HAE}$ than in the non-HAE+non- $\mathrm{HBO}_{2}$ T group rats $(P<0.05$, Table 1). Brain levels of these 3 oxidative stress markers 


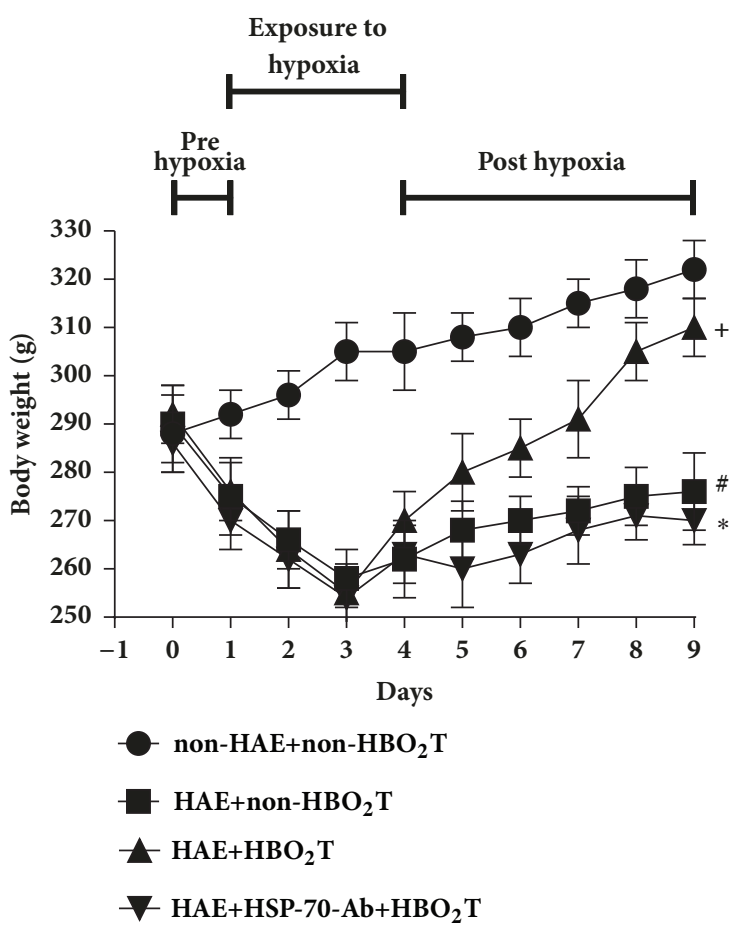

(a)

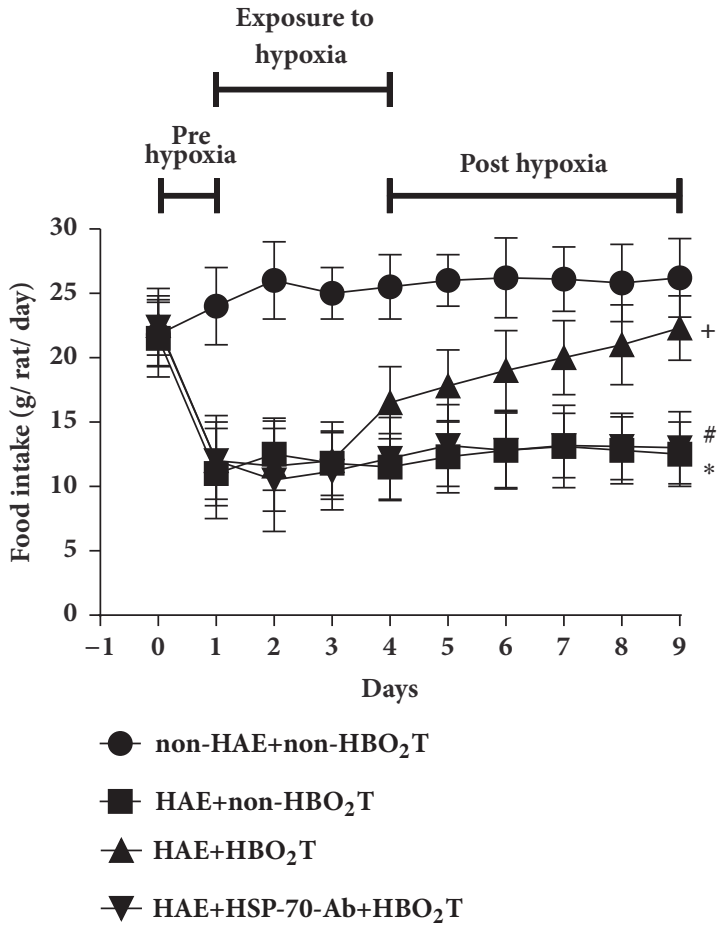

(b)

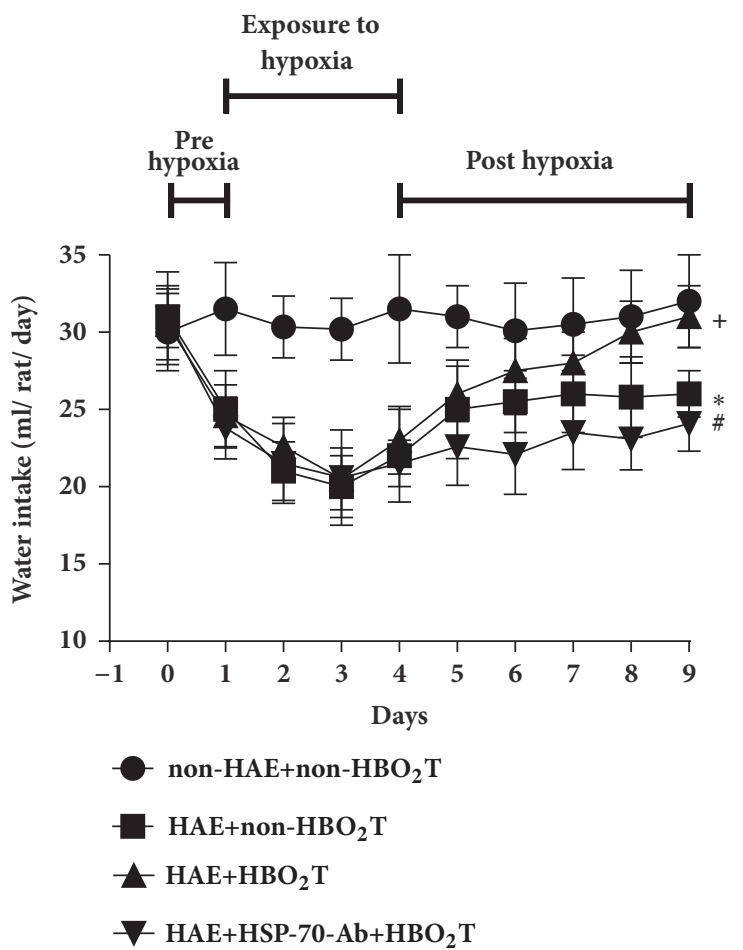

(c)

FIGURE 2: Mean \pm SD body weight in gram (a), food intake in gram (b), and water content in milliliter (c) per day for non-HAE+non-

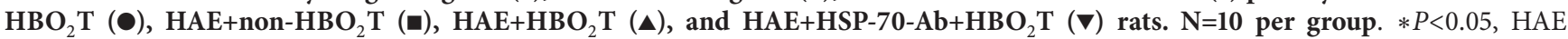
group versus non-HAE group; $+p<0.05, \mathrm{HAE}+\mathrm{HBO}_{2} \mathrm{~T}$ versus $\mathrm{HAE}+$ non- $\mathrm{HBO}_{2} \mathrm{~T}$ group; $\# p<0.05, \mathrm{HAE}+\mathrm{HSP}-70-\mathrm{Ab}+\mathrm{HBO}_{2} \mathrm{~T}$ group versus $\mathrm{HAE}+\mathrm{HBO}_{2} \mathrm{~T}$ group. 


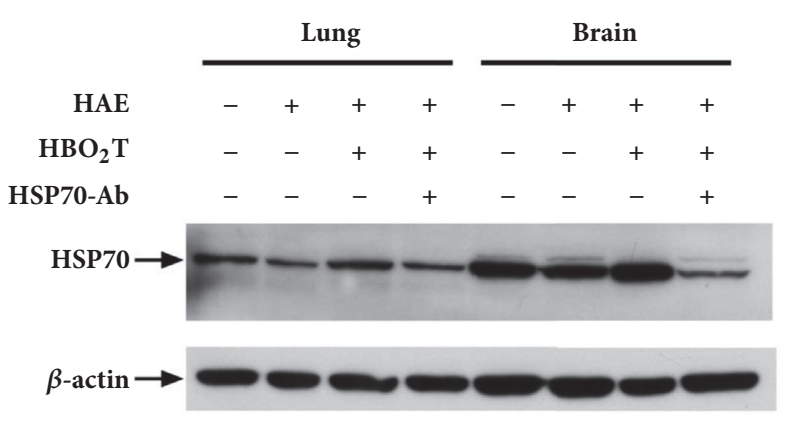

(a)

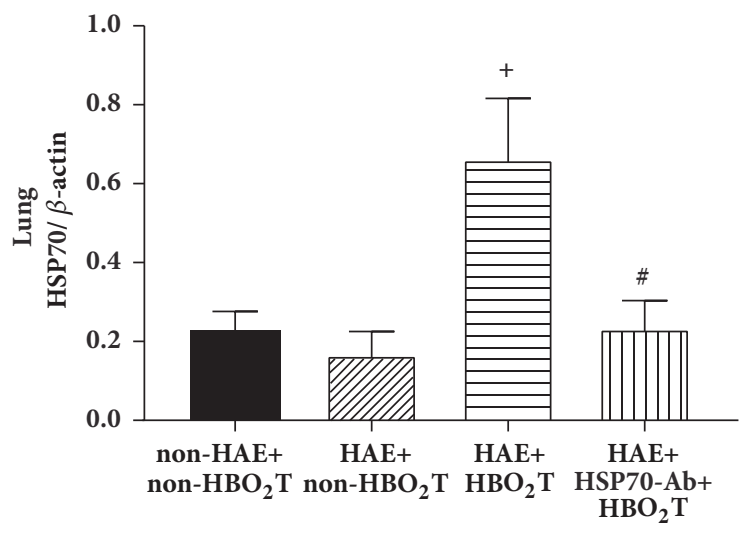

(b)

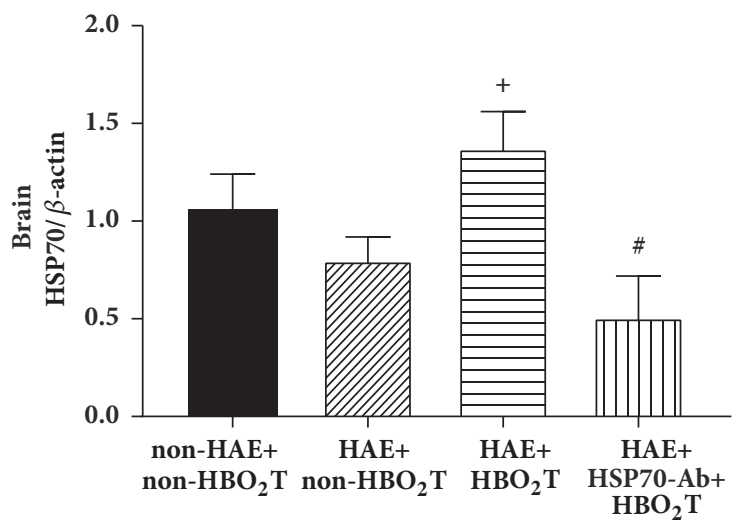

(c)

Figure 3: Densitometer analysis of the relative expression of HSP-70 by lung and brain (or hippocampus) tissue samples obtained from the non-HAE rats received non- $\mathrm{HBO}_{2} \mathrm{~T}$ (non-HAE+non- $\mathrm{HBO}_{2} \mathrm{~T}$ ), the $\mathrm{HAE}$ rats received non- $\mathrm{HBO}_{2} \mathrm{~T}\left(\mathrm{HAE}+\right.$ non- $\mathrm{HBO} \mathrm{T}_{2} \mathrm{~T}$ ), the $\mathrm{HAE}$ rats received non- $\mathrm{HBO}_{2} \mathrm{~T}\left(\mathrm{HAE}+\mathrm{non}-\mathrm{HBO}_{2} \mathrm{~T}\right)$, and the $\mathrm{HAE}$ rats received $\mathrm{HSP}-70-\mathrm{Ab}$ and $\mathrm{HBO}_{2} \mathrm{~T}(\mathrm{HAE}+\mathrm{HSP}-70-\mathrm{Ab}+\mathrm{HBO} 2 \mathrm{~T})$. (a) Representative immunoblot of HSP-70. Quantification of (b) lung and (c) brain HSP-70 expression levels compared to $\beta$-actin control in each groups. $* p<0.05$ compared with the (HAE + non $\left.-\mathrm{HBO}_{2} \mathrm{~T}\right) ;+p<0.05$ compared with the $\mathrm{HAE}+\mathrm{HBO}_{2} \mathrm{~T}$ group. Bars represented the mean $\pm \mathrm{SD}$ of ten rats per group.

were significantly $(\mathrm{P}<0.05)$ lower in the $\mathrm{HAE}+\mathrm{HBO}_{2} \mathrm{~T}$ group rats than in the $\mathrm{HAE}+$ non- $\mathrm{HBO}_{2} \mathrm{~T}$ group rats $(P<0.05)$. The beneficial effects of $\mathrm{HBO}_{2} \mathrm{~T}$ were significantly reduced in the $\mathrm{HAE}+\mathrm{HSP}-70-\mathrm{Ab}+\mathrm{HBO}_{2} \mathrm{~T}$ group rats $(P<0.05$, Table 1$)$.

3.6. $\mathrm{HBO}_{2} \mathrm{~T}$ Reversed Both the Decreased GSH System and Decreased Antioxidant Enzyme in the Brain of HAE Rats. Brain expression levels of both GSH (the primary antioxidant in the cell) and GSH/GSSG ratio in the HAE+non- $\mathrm{HBO}_{2} \mathrm{~T}$ group rats were significantly $(P<0.05)$ lower than in the non$\mathrm{HAE}+$ non $-\mathrm{HBO}_{2} \mathrm{~T}$ group rats (Table 1). In contrast, after 3 days of HAE, the hippocampal GSSG (a prooxidant enzyme) was significantly higher $(P<0.05)$ in the $\mathrm{HAE}+$ non- $-\mathrm{HBO}_{2} \mathrm{~T}$ group than in the non-HAE+non- $\mathrm{HBO}_{2} \mathrm{~T}$ group rats. In $\mathrm{HAE}$ rats, $\mathrm{HBO}_{2} \mathrm{~T}$ significantly reversed the decreased GSH, the decreased GSH/GSSG, and the increased GSSG levels in the brain $(P<0.05$, Table 1$)$. Again, the beneficial effects of $\mathrm{HBO}_{2} \mathrm{~T}$ were significantly attenuated in the HAE+HSP$70 \mathrm{Ab}+\mathrm{HBO}_{2} \mathrm{~T}$ group (Table 1 ). In addition, $\mathrm{HBO}_{2} \mathrm{~T}$ significantly reversed post-HAE decreased levels of several antioxidant enzymes including SOD, GPx, and GR in the brain $(P<0.05$; Table 1$)$. The beneficial effects of $\mathrm{HBO}_{2} \mathrm{~T}$ were significantly reduced by HSP-70 Ab $(P<0.05$; Table 1$)$.

3.7. $\mathrm{HBO}_{2} \mathrm{~T}$ Reversed the Increased Brain Levels of Proinflammatory Cytokines in HAE Rats. Levels of cytokines interleukin-1 $\beta$ (IL-1 $\beta$ ), IL-6, interferon- (INF-) $\gamma$, and tumor necrosis factor- (TNF-) $\alpha$ in brain tissue lysate at 5 days after HAE measured using a commercially available ELISA array are summarized in Table 2. All four measured cytokine levels exhibited significant increases in the $\mathrm{HAE}+$ non $-\mathrm{HBO}_{2} \mathrm{~T}$ group rats than did the non-HAE+non- $\mathrm{HBO}_{2} \mathrm{~T}$ control group rats $(P<0.05$; Table 2$) . \mathrm{HBO}_{2} \mathrm{~T}$ significantly attenuated the HAE-induced brain levels of all four cytokines in the $\mathrm{HAE}+\mathrm{HBO}_{2} \mathrm{~T}$ group of rats. Again, the beneficial effects of $\mathrm{HBO}_{2} \mathrm{~T}$ were significantly reduced by inhibition of brain HSP-70 with HSP-70 Ab in the HAE+HSP-70 Ab+HBO $2 \mathrm{~T}$ group rats (Table 2 ).

3.8. $\mathrm{HBO}_{2} \mathrm{~T}$ Attenuated Lung Inflammation in HAE Rats. After 3 days of HAE, the values of BAL fluid levels of MPO $(100 \mu \mathrm{g} / \mathrm{mg}$ protein versus $300 \mu \mathrm{g} / \mathrm{mg}$ protein), IL-6 (8 pg/mL 


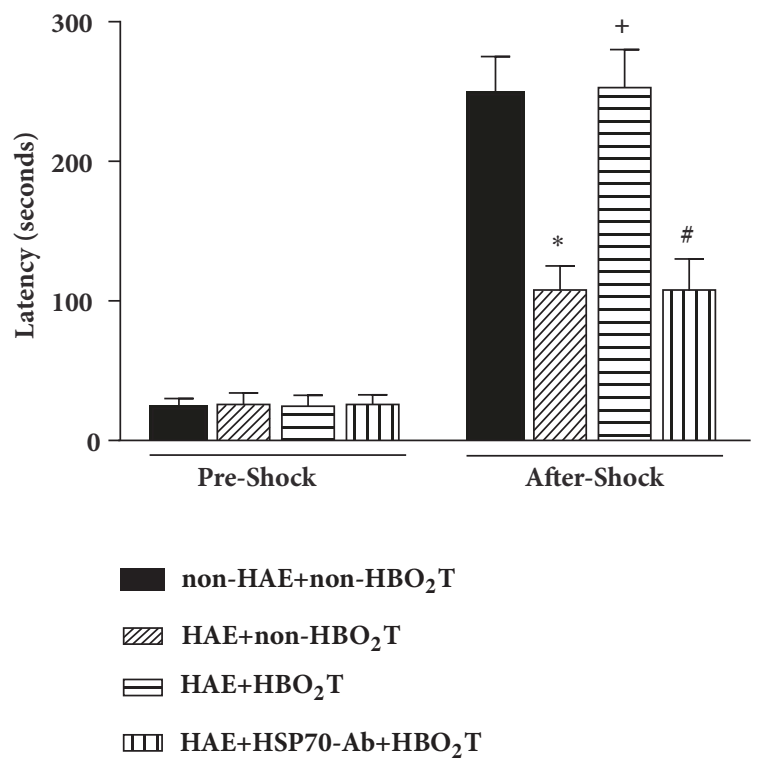

(a)

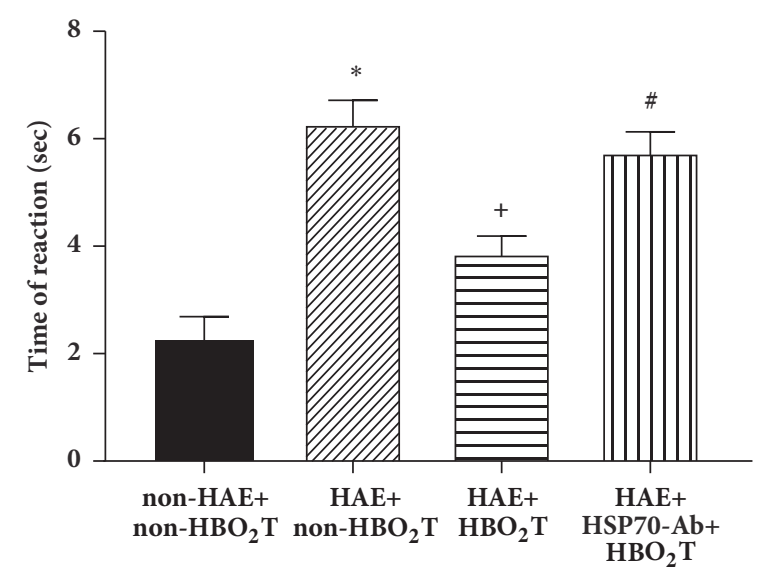

(b)

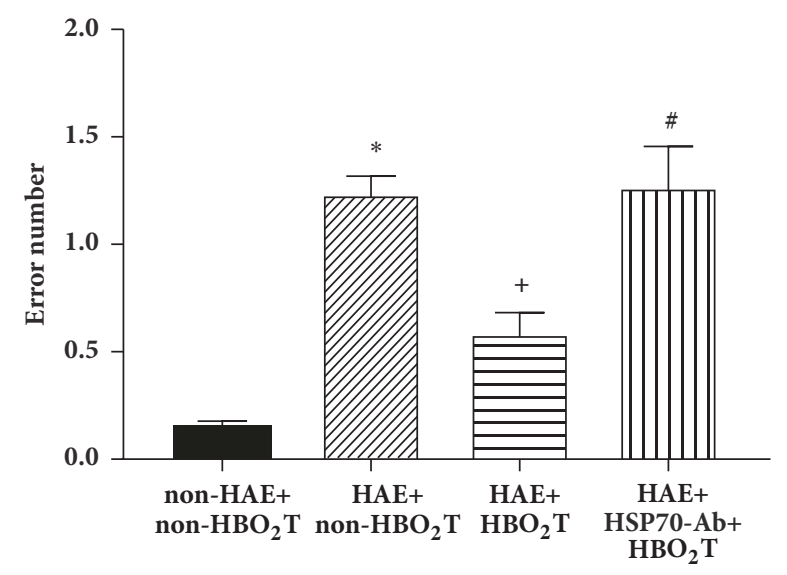

(c)

Figure 4: (a) Comparison of latency to entering the dark chamber before receiving the foot shock (preshock; acquisition time) and $24 \mathrm{~h}$ after receiving the foot shock (after $24 \mathrm{~h}$; retention time). Each column and bar represents the mean \pm SD of 10 rats per group. The acquisition time did not significantly differ among the four groups. However, the retention time was significantly lower in the $\mathrm{HAE}+$ non- $\mathrm{HBO} 2 \mathrm{~T}$ group compared with the non-HAE+non- $\mathrm{HBO}_{2} \mathrm{~T}$ controls at 5 days after injury $(* P<0.05)$. The $\mathrm{HAE}+\mathrm{HBO}_{2} \mathrm{~T}$ group rats showed a significant increase of retention time in passive avoidance test $\left({ }^{+} P<0.05\right)$. However, the HAE $+\mathrm{HSP}-70 \mathrm{Ab}+\mathrm{HBO}_{2} \mathrm{~T}$ group rats showed a significant decrease of retention time in passive avoidance compared with the $\mathrm{HAE}+\mathrm{HBO}_{2} \mathrm{~T}$ group $\left({ }^{\#} P<0.05\right)$. The $\mathrm{Y}$-maze test evaluates learning and spatial memory function in rats 5 days after HAE. Data of both time of reaction (b) and error number (c) are presented as means \pm SD of $\mathrm{n}=10$ per group. The Y-maze test results showed that the HAE animals had a deficit in spatial memory (time of reaction prolonged and error number increased) compared with the non-HAE+non- $\mathrm{HBO}_{2} \mathrm{~T}$ controls at 5 days after injury $(* P<0.05)$. The $\mathrm{HAE}_{+} \mathrm{HBO}_{2} \mathrm{~T}$ group rats showed a significant decrease of time of reaction and error number in Y-maze test with the HAE+non- $\mathrm{HBO}_{2} \mathrm{~T}$ group $\left({ }^{+} P<0.05\right)$. However, the $\mathrm{HAE}+\mathrm{HSP}-70 \mathrm{Ab}+\mathrm{HBO}_{2} \mathrm{~T}$ group rats showed a significant increase of time of reaction and error number in Y-maze test compared with the $\mathrm{HAE}+\mathrm{HBO}_{2} \mathrm{~T}$ group $\left({ }^{\#} P<0.05\right)$

versus $49 \mathrm{pg} / \mathrm{mL})$, IL-1 $\beta(12 \mathrm{pg} / \mathrm{mL}$ versus $65 \mathrm{pg} / \mathrm{mL})$, and TNF- $\alpha(6 \mathrm{pg} / \mathrm{mL}$ versus $49 \mathrm{pg} / \mathrm{mL})$ in the $\mathrm{HAE}+$ non $-\mathrm{HBO}_{2} \mathrm{~T}$ group were significantly higher than those of the non$\mathrm{HAE}+$ non- $\mathrm{HBO}_{2} \mathrm{~T}$ group $(P<0.05, \mathrm{n}=12$ each group) (Figure 7). In contrast, as compared with those of the HAE+ non$\mathrm{HBO}_{2} \mathrm{~T}$ group, the $\mathrm{HAE}+\mathrm{HBO}_{2} \mathrm{~T}$ group had significantly lower values of MPO (120 $\mu \mathrm{g} / \mathrm{mg}$ protein), IL-6 $(15 \mathrm{pg} / \mathrm{mL})$, IL-1 $\beta(19 \mathrm{pg} / \mathrm{mL})$, and TNF- $\alpha(17 \mathrm{pg} / \mathrm{mL})(P<0.05, \mathrm{n}=12$ per group) (Figure 7). The beneficial effects of $\mathrm{HBO}_{2} \mathrm{~T}$ were significantly attenuated by HSP-70 Ab treatment (Figure 7).

\section{Discussion}

Our present study tested the protection of $\mathrm{HBO}_{2} \mathrm{~T}$ as a therapeutic option for the acute therapy of high-mountain sickness in rats. We found that a regimen of $\mathrm{HBO}_{2} \mathrm{~T}\left(100 \% \mathrm{O}_{2}\right.$ 
TABLE 2: Proinflammatory cytokine level expression in the hippocampus of rat brain of all four groups.

\begin{tabular}{|c|c|c|c|c|}
\hline $\begin{array}{l}\text { Parameters } \\
\text { (pg/mg protein) }\end{array}$ & $\begin{array}{l}\text { non-HAE+ } \\
\text { non- } \mathrm{HBO}_{2} \mathrm{~T}\end{array}$ & $\begin{array}{c}\text { HAE+ } \\
\text { non- } \mathrm{HBO}_{2} \mathrm{~T}\end{array}$ & $\begin{array}{l}\mathrm{HAE}+ \\
\mathrm{HBO}_{2} \mathrm{~T}\end{array}$ & $\begin{array}{c}\mathrm{HAE}+\mathrm{HSP}-70 \mathrm{Ab}+ \\
\mathrm{HBO}_{2} \mathrm{~T} \\
\end{array}$ \\
\hline TNF- $\alpha$ & $31 \pm 10$ & $62 \pm 12 *$ & $39 \pm 11^{+}$ & $58 \pm 13^{\#}$ \\
\hline IL- $1 \beta$ & $37 \pm 11$ & $165 \pm 24 *$ & $62 \pm 12^{+}$ & $171 \pm 25^{\#}$ \\
\hline IL-6 & $113 \pm 27$ & $448 \pm 86 *$ & $203 \pm 56^{+}$ & $459 \pm 97^{\#}$ \\
\hline INF- $\gamma$ & $24 \pm 10$ & $49 \pm 21 *$ & $22 \pm 13^{+}$ & $53 \pm 24^{\#}$ \\
\hline
\end{tabular}

The cytokine levels are given as mean $\pm \mathrm{SD}$ of 10 rats per group. $* P<0.05$, compared with non- $\mathrm{HBO}_{2} \mathrm{~T}$ group; ${ }^{+} P<0.05$, compared with $\mathrm{HAE}+$ non- $\mathrm{HBO}{ }_{2} \mathrm{~T}$ group; and ${ }^{\#} P<0.05$, compared with $\mathrm{HAE}+\mathrm{HBO}_{2}$ T group. See Figure 1 legend for group abbreviations.

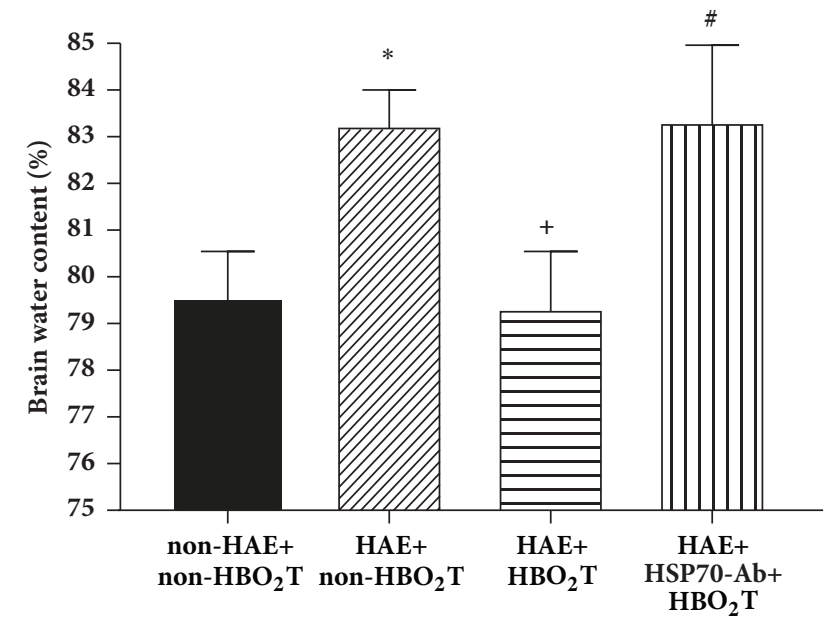

(a)

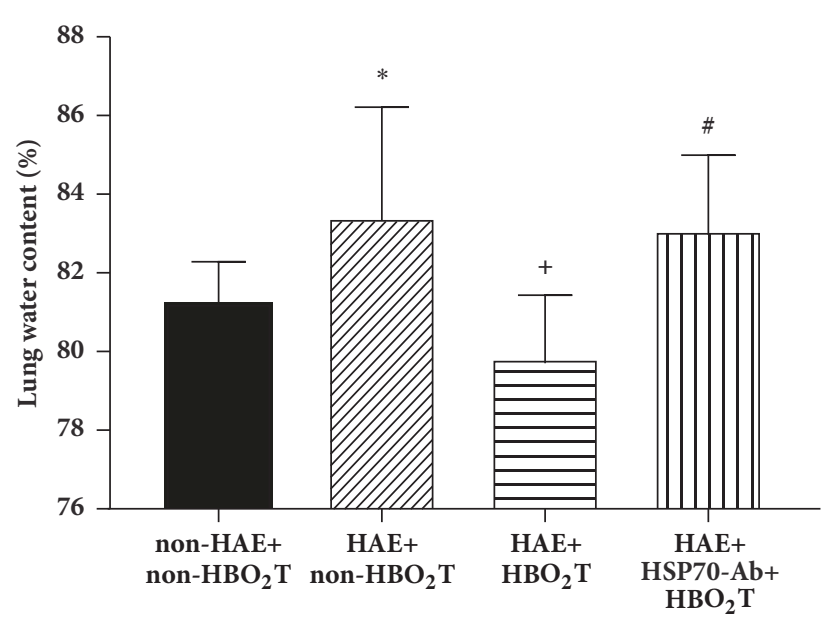

(b)

Figure 5: Effect of $\mathrm{HBO}_{2} \mathrm{~T}$ on both (a) brain and (b) lung water contents (\%) in rats 5 days after HAE. Data are means $\pm \mathrm{SD}$ of $\mathrm{n}=10$ per group. $* P<0.05$ for $\mathrm{HAE}+$ non- $\mathrm{HBO}_{2} \mathrm{~T}$ group versus non-HAE+non- $\mathrm{HBO}_{2} \mathrm{~T}$ group; ${ }^{+} P<0.05$ for $\mathrm{HAE}+\mathrm{HBO}_{2} \mathrm{~T}$ group versus $\mathrm{HAE}+$ non- $\mathrm{HBO}{ }_{2} \mathrm{~T}$ group; ${ }^{\#} P<0.05$ for the $\mathrm{HAE}+\mathrm{HSP}-70 \mathrm{Ab}+\mathrm{HBO}_{2} \mathrm{~T}$ group versus the $\mathrm{HAE}+\mathrm{HBO}_{2}$ T group.

at 2.0 absolute atmospheres for $1 \mathrm{~h}$ per day for 5 consecutive days) immediately after HAE injury has protective potential in an animal model of HAE. This study provides the following main findings: (i) the $\mathrm{HBO}_{2} \mathrm{~T}$ can increase brain and lung expression of HSP-70; (ii) the $\mathrm{HBO}_{2} \mathrm{~T}$ can improve passive avoidance learning and spatial memory dysfunction of the rat after HAE; (iii) the $\mathrm{HBO}_{2} \mathrm{~T}$ can attenuate post-HAE cerebral edema; (iv) the $\mathrm{HBO}_{2} \mathrm{~T}$ can reverse post-HAE decreased expression of GSH (the main antioxidant in the cell), decreased expression of SOD and GPx (the antioxidant enzymes), and increased GSSG (the main prooxidant in the cell) in the brain; (v) the $\mathrm{HBO}_{2} \mathrm{~T}$ can decrease pot-HAE overexpression of proinflammatory cytokines including IL$1 \beta$, IL-6, IFN- $\gamma$, and TNF- $\alpha$ in the brain; and (vi) the $\mathrm{HBO}_{2} \mathrm{~T}$ can attenuate post-HAE induction of pulmonary edema and inflammation. In the present study, we confirm for the first time that post-HAE administration of $\mathrm{HBO}_{2} \mathrm{~T}$ attenuates simulated high-mountain sickness syndromes characterized by cerebral and pulmonary edema and the complications. We further elucidate that the beneficial effects of post-HAE $\mathrm{HBO}_{2} \mathrm{~T}$ in reducing high-mountain sickness can be blocked by reducing the HSP-70 expression with HSP-70 antibody.

Hyperbaric oxygen therapy is defined as breathing $100 \%$ oxygen under increased atmospheric pressure [25]. If descent is impossible, $\mathrm{HBO}_{2} \mathrm{~T}$ is highly recommended during the acute phase of the HAE-induced pulmonary edema in patients [26].

Additionally, our present results show that $\mathrm{HBO}_{2} \mathrm{~T}$ attenuates HAE-induced brain and pulmonary edema by inducing the HSP-70 expression in rat brain and lung. Our data are consistent with many pervious investigations. For example, a recent study shows that decreasing or increasing HSP-70 exacerbates or attenuates heat-induced cell death, respectively, in rat hypothalamic cells [8]. Stronger HSP70 immunoreactivity was related to smaller infarction and better functional outcomes [27]. Overexpression of HSP-70 achieved the neuroprotective effect via antiapoptotic mechanisms [28]. HSP-70 protected against apoptotic cell death induced by nuclear factor $-\kappa \mathrm{B}$ activation and the nitric oxide synthase II-peroxynitrite signalling cascade in hippocampal CA3 and glial cells [29]. Extracellular HSP-70 can promote neuron death by mediating the production of cytotoxic levels of tumor necrosis factor-alpha [30]. In the present study, $\mathrm{HBO}_{2} \mathrm{~T}$ induced an $80 \%$ higher expression of HSP-70 in both the brain and lung tissues. Reduction of this relatively mild HSP-70 expression in both the hippocampal and lung tissues with HSP-70 Ab completely reversed the $\mathrm{HBO}_{2} \mathrm{~T}$-induced protection. Our results showed that, after HAE injury, intravenously administrated HSP-70 neutralizing antibodies reduced the expression of antigen in hippocampal and lung 


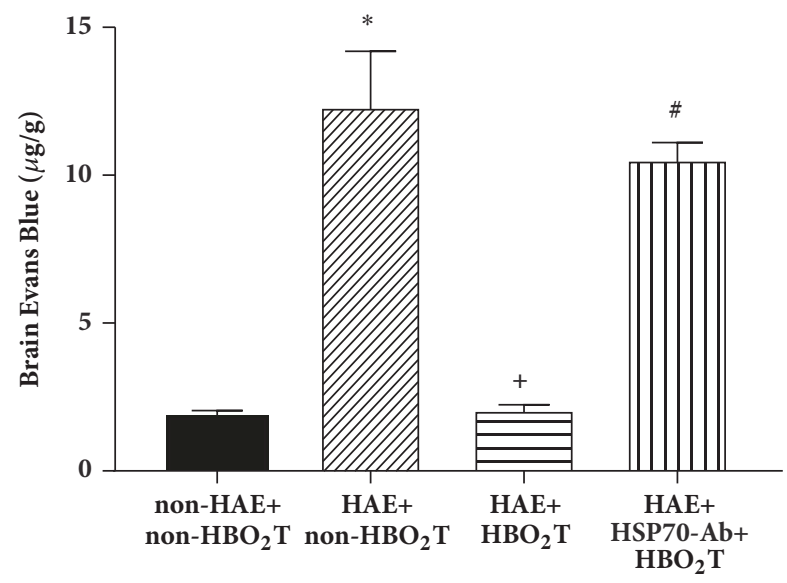

(a)

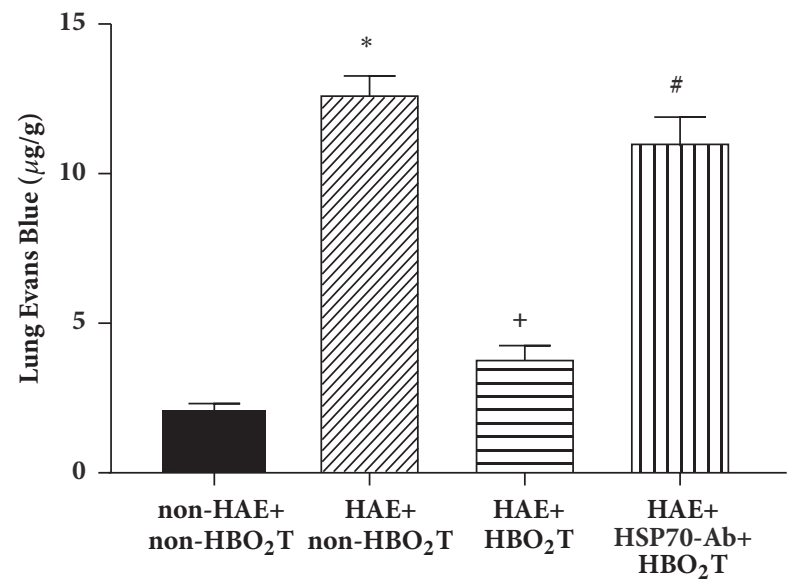

(b)

Figure 6: Effects of $\mathrm{HBO}_{2} \mathrm{~T}$ on Evans Blue extravasation of both brain (a) and lung (b) tissues in rats 5 days after HAE. Data are represented as the mean $\pm \mathrm{SD}$ of $\mathrm{n}=10$ per group. $* P<0.05$ for $\mathrm{HAE}+$ non- $\mathrm{HBO}_{2} \mathrm{~T}$ group versus non-HAE+ non- $\mathrm{HBO}_{2} \mathrm{~T}$ group group; ${ }^{+} P<0.05$ for $\mathrm{HAE}+\mathrm{HBO}_{2} \mathrm{~T}$ group versus $\mathrm{HAE}+$ non $-\mathrm{HBO}_{2} \mathrm{~T}$ group; ${ }^{\#} \mathrm{P}<0.05$ for the $\mathrm{HAE}+\mathrm{HSP}-70 \mathrm{Ab}+\mathrm{HBO}_{2} \mathrm{~T}$ group versus $\mathrm{HAE}+\mathrm{HBO}_{2} \mathrm{~T}$ group.

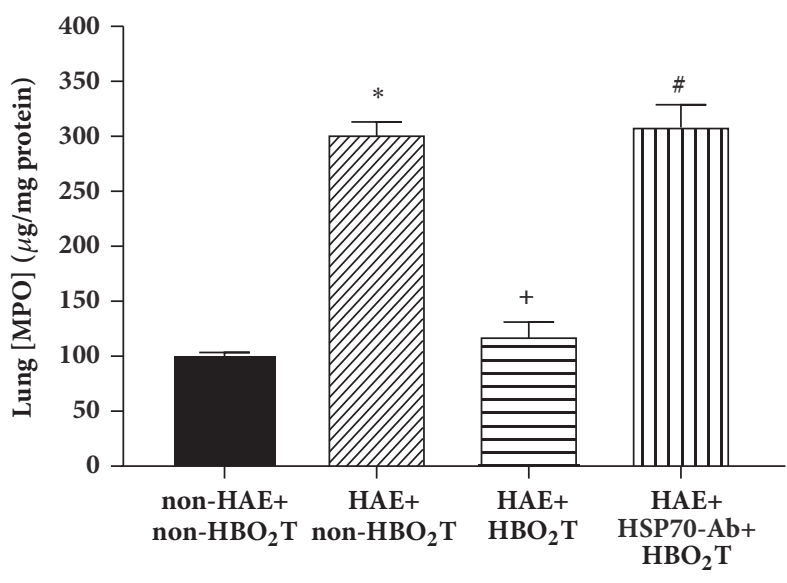

(a)

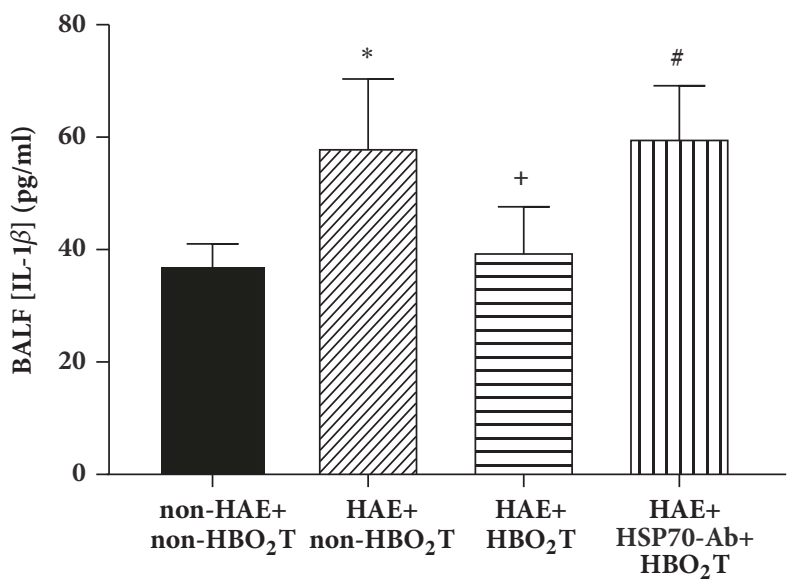

(c)

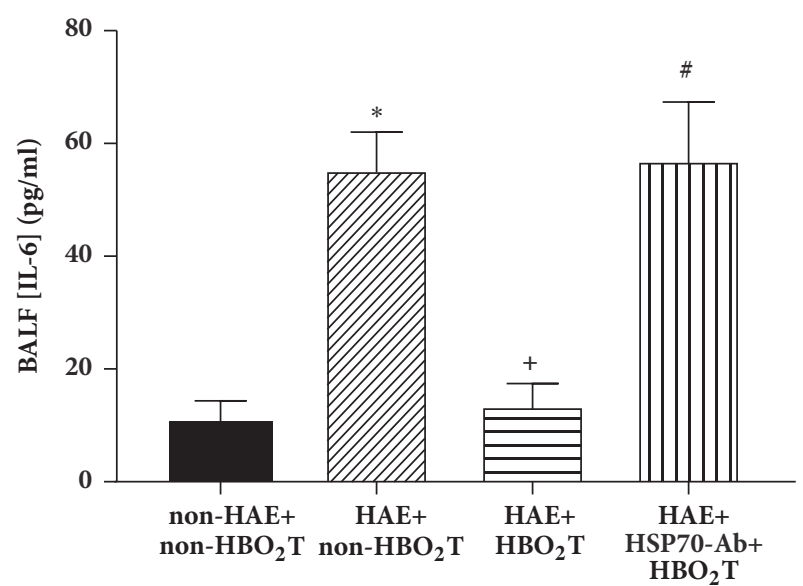

(b)

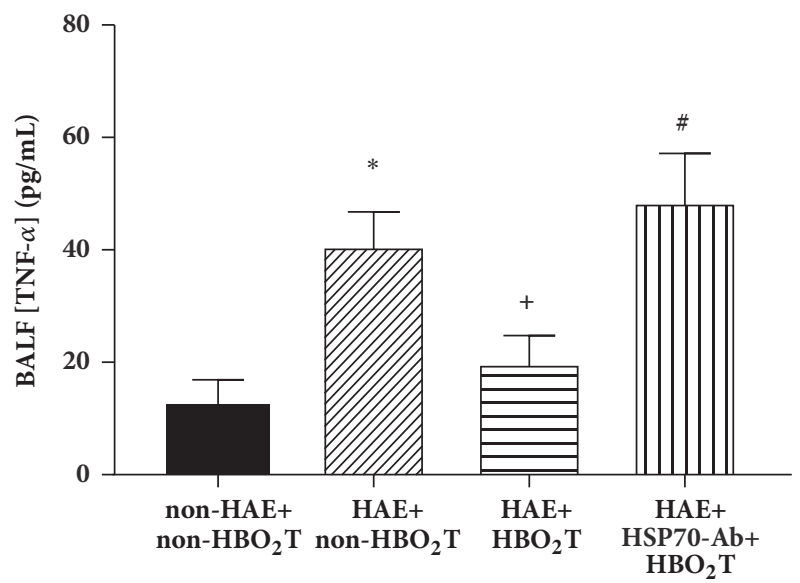

(d)

Figure 7: Effect of $\mathrm{HBO}_{2}$ T on lung levels of (a) myeloperoxidase (MPO) and bronchoalveolar (BAL) fluid levels of (b) interleukin-6 (IL-6), (c) IL- $1 \beta$, and (d) tumor necrosis factor- $\alpha$ (TNF- $\alpha$ ) in rats 5 days after HAE. Data are presented as the means \pm SD of $n=10$ per group. $* P<0.05$ for $\mathrm{HAE}+$ non- $\mathrm{HBO}_{2}$ T group versus non-HAE + non- $\mathrm{HBO}_{2} \mathrm{~T}$ group; ${ }^{+} P<0.05$ for $\mathrm{HAE}+\mathrm{HBO}_{2} \mathrm{~T}$ group versus $\mathrm{HAE}+$ non- $\mathrm{HBO} \mathrm{O}_{2} \mathrm{~T}$ group; ${ }^{\#} P<0.05$ for the $\mathrm{HAE}+\mathrm{HSP}-70 \mathrm{Ab}+\mathrm{HBO}_{2} \mathrm{~T}$ group versus $\mathrm{HAE}+\mathrm{HBO}_{2} \mathrm{~T}$ group. 
tissues. Based on the findings of Liebelt et al. [31], HSP-70 Ab may penetrate into the brain via damaged blood-brain barrier to reduce the beneficial effects of $\mathrm{HBO}_{2} \mathrm{~T}$ in brain edema and cognitive deficits by neutralizing HSP-70 produced in the rat hippocampus.

Hyperbaric oxygen therapy has been shown to ameliorate brain injury in a variety of animal models [32]. Hyperbaric oxygen therapy is related to reduced cerebral edema, decreased inflammation, decreased apoptotic cell death, and increased neural regeneration. Indeed, as demonstrated in the present results, $\mathrm{HBO}_{2} \mathrm{~T}$ reversed the HAE-induced a decrease of GSH (the main antioxidant in the cell), an increase of GSSG (the main prooxidant in the cell), a decrease of GSH/GSSG, and a decrease in the activity of SOD, GPx, and GR (the antioxidant enzymes) in the brain. In addition, $\mathrm{HBO}_{2} \mathrm{~T}$ reversed the HAE-induced upregulation of brain levels of proinflammatory cytokines including IL-1 $\beta$, IL-6, TNF$\alpha$, and IF- $\gamma$ as well as cognitive deficits. Hypoxia increases brain water content and blood-brain barrier permeability by inducing inflammation $[11,33]$. The aquaporin-4 plays a key role in controlling cellular water content as well as cerebral edema formation $[34,35]$. These observations suggest that $\mathrm{HBO}_{2} \mathrm{~T}$ may inhibit high-altitude cerebral and pulmonary edema by modulating both inflammation and aquaporin- 4 levels in situ.

Previous result have shown both food consumption and body weight loss in rats exposed to high altitude compared with rats raised in the low-altitude condition [36, 37]. Highly efficient energy utilization and metabolic homeostasis maintenance rely on hypothalamic neuromodulation [38]. In the present results, $\mathrm{HBO}_{2} \mathrm{~T}$ might attenuate $\mathrm{HAE}$-induced reduced food consumption and body weight by attenuating brain edema.

The hypothalamus is a critical regulator of numerous endocrine and autonomic functions [38]. It may be involved in physiological stress responses, blood volume regulation, glucose regulation, thermoregulation, feeding behaviour, and/or circadian rhythms [36]. In the present results, the $\mathrm{HAE}+$ non- $\mathrm{HBO}_{2} \mathrm{~T}$ rats exhibited brain (including hypothalamus, hippocampus, and others) edema, which led to reduced food consumption, body weight loss, cognitive deficits, and pulmonary edema. Our data suggest that injury of brain tissue is related to the inability to withstand hypobaric hypoxia stress. However, the overexpression of the HSP70 in the $\mathrm{HAE}+\mathrm{HBO}_{2} \mathrm{~T}$ rats reduced hypothalamic and/or hippocampus damage from the HAE stress, permitting the HSP-70-mediated HAE $+\mathrm{HBO}_{2} \mathrm{~T}$ animals better adaptation.

\section{Conclusion}

In summary, the $\mathrm{HAE}+$ non- $\mathrm{HBO}_{2} \mathrm{~T}$ rats exhibited brain (including hypothalamus and hippocampus, and others) edema or injury, which might lead to reduced food consumption, body weight loss, cognitive deficits, and pulmonary edema. Brain tissue injury may result in the inability to withstand HAE stress. However, the overexpression of brain HSP70 in the $\mathrm{HAE}+\mathrm{HBO}_{2} \mathrm{~T}$ rats reduced brain edema or damage from the HAE stress, permitting the HSP-70-mediated $\mathrm{HAE}+\mathrm{HBO}_{2} \mathrm{~T}$ animals better adaptation. Our results indicate that $\mathrm{HBO}_{2} \mathrm{~T}$ works on a remodeling of brain/ lung to exert a protective effect against simulated high-mountain sickness via enhancing HSP-70 expression in HAE rats.

$\begin{array}{ll}\text { Abbreviations } \\ \text { HAE: } & \text { High-altitude exposure } \\ \text { HBO2T: } & \text { Hyperbaric oxygen therapy } \\ \text { HSP-70: } & \text { Heat shock protein } 70 \\ \text { 2,3-DHBA: } & \text { 2,3-dihydroxybenzoic acid } \\ \text { NOx: } & \text { Nitric oxide metabolites } \\ \text { MOD: } & \text { Malondialdehyde } \\ \text { GSH: } & \text { Reduced glutathione } \\ \text { GSSG: } & \text { Oxidized glutathione } \\ \text { GPx: } & \text { Glutathione peroxidase } \\ \text { GR: } & \text { Glutathione reductase } \\ \text { SOD: } & \text { Superoxide dismutase } \\ \text { TNF- } \alpha: & \text { Tumor necrosis factor-alpha } \\ \text { IL-1 } \beta: & \text { Interleukin-1 beta } \\ \text { BAL: } & \text { Bronchoalveolar. }\end{array}$

\section{Data Availability}

The data used to support the findings of this study are available from the corresponding author upon request.

\section{Ethical Approval}

The animal and research protocols used in this study followed the guidelines of the Animal Ethics Committee of Chi Mei Medical Center (Tainan, Taiwan) (Institutional Animal Care and Use Committee (IACUC) Approval no. 101122406-1) under Guidelines of the Ministry of Science and Technology of the Republic of China (Taipei, Taiwan). All efforts were made to minimize the number of animals used and their suffering.

\section{Conflicts of Interest}

The authors declare that no conflicts of interest exist.

\section{Authors' Contributions}

Hsing-Hsien $\mathrm{Wu}$, Ching-Ping Chang, and Chia-Ti Wang conceived and designed the manuscript. Ko-Chi Niu, ChengHsien Lin, and Hung-Jung Lin contributed the data analysis and references. Hsing-Hsien Wu contributed the core facility, experiment protocol, and data explanations of this manuscript. Ko-Chi Niu and Cheng-Hsien Lin performed the experiments. Ching-Ping Chang and Chia-Ti Wang wrote the manuscript.

\section{Acknowledgments}

This study was supported in part by a grant from the Ministry of Science and Technology of the Republic of China (Grant no. NSC 101-2314-B-218-001-MY3). Also, the authors wish 
to thank Ms. Meng-Tsung Ho for her excellent editorial assistance in manuscript preparation.

\section{References}

[1] C. Clarke, "Acute mountain sickness: Medical problems associated with acute and subacute exposure to hypobaric hypoxia," Postgraduate Medical Journal, vol. 82, no. 973, pp. 748-753, 2006.

[2] R. C. Roach and P. H. Hackett, "Frontiers of hypoxia research: Acute mountain sickness," Journal of Experimental Biology, vol. 204, no. 18, pp. 3161-3170, 2001.

[3] M.-C. Tsai, H.-J. Lin, M.-T. Lin, K.-C. Niu, C.-P. Chang, and T. C.-Y. Tsao, "High-altitude pulmonary edema can be prevented by heat shock protein 70-mediated hyperbaric oxygen preconditioning," Journal of Trauma and Acute Care Surgery, vol. 77, no. 4, pp. 585-591, 2014.

[4] H. Lin, C.-P. Chang, H.-J. Lin, M.-T. Lin, and C.-C. Tsai, "Attenuating brain edema, hippocampal oxidative stress, and cognitive dysfunction in rats using hyperbaric oxygen preconditioning during simulated high-altitude exposure," Journal of Trauma and Acute Care Surgery, vol. 72, no. 5, pp. 1220-1227, 2012.

[5] Z. Li, C. Gao, Y. Wang et al., "Reducing pulmonary injury by hyperbaric oxygen preconditioning during simulated high altitude exposure in rats," Journal of Trauma - Injury Infection and Critical Care, vol. 71, no. 3, pp. 673-679, 2011.

[6] R. G. Giffard and M. A. Yenari, "Many Mechanisms for Hsp70 Protection from Cerebral Ischemia," Journal of Neurosurgical Anesthesiology, vol. 16, no. 1, pp. 53-61, 2004.

[7] Y. Matsumori, S. M. Hong, K. Aoyama et al., "Hsp70 overexpression sequesters AIF and reduces neonatal hypoxic/ischemic brain injury," Journal of Cerebral Blood Flow \& Metabolism, vol. 25, no. 7, pp. 899-910, 2005.

[8] K.-C. Lin, H.-J. Lin, C.-P. Chang, and M.-T. Lin, "Decreasing or increasing heat shock protein 72 exacerbates or attenuates heatinduced cell death, respectively, in rat hypothalamic cells," FEBS Open Bio, vol. 5, pp. 724-730, 2015.

[9] B. Qu, Y. Jia, Y. Liu, H. Wang, G. Ren, and H. Wang, "The detection and role of heat shock protein 70 in various nondisease conditions and disease conditions: a literature review," Cell Stress and Chaperones, vol. 20, no. 6, pp. 885-892, 2015.

[10] Z. Sun, X. Jiang, Y. Cheng et al., "Exendin-4 inhibits highaltitude cerebral edema by protecting against neurobiological dysfunction," Neural Regeneration Research, vol. 13, no. 4, pp. 653-663, 2018.

[11] H. Patir, S. K. S. Sarada, S. Singh, T. Mathew, B. Singh, and A. Bansal, "Quercetin as a prophylactic measure against high altitude cerebral edema," Free Radical Biology \& Medicine, vol. 53, no. 4, pp. 659-668, 2012.

[12] C.-C. Chio, H.-J. Lin, Y.-F. Tian et al., "Exercise attenuates neurological deficits by stimulating a critical HSP70/NF-KB/IL6/synapsin I axis in traumatic brain injury rats," Journal of Neuroinflammation, vol. 14, no. 1, p. 90, 2017.

[13] N. Hosseini, H. Alaei, P. Reisi, and M. Radahmadi, "The effect of treadmill running on passive avoidance learning in animal model of Alzheimer disease," International Journal of Preventive Medicine, vol. 4, no. 2, pp. 187-192, 2013.

[14] J. Wei, X. Pan, Z. Pei et al., "The beta-lactam antibiotic, ceftriaxone, provides neuroprotective potential via anti-excitotoxicity and anti-inflammation response in a rat model of traumatic brain injury," Journal of Trauma and Acute Care Surgery, vol. 73, no. 3, pp. 654-660, 2012.

[15] H. T. Hassoun, R. A. Kozar, B. C. Kone, H. J. Safi, and F. A. Moore, "Intraischemic hypothermia differentially modulates oxidative stress proteins during mesenteric ischemia/reperfusion," Surgery, vol. 132, no. 2, pp. 369-376, 2002.

[16] H. Togashi, K. Mori, K.-I. Ueno et al., "Consecutive evaluation of nitric oxide production after transient cerebral ischemia in the rat hippocampus using in vivo brain microdialysis," Neuroscience Letters, vol. 240, no. 1, pp. 53-57, 1998.

[17] L. K. Dahle, E. G. Hill, and R. T. Holman, "The thiobarbituric acid reaction and the autoxidations of polyunsaturated fatty acid methyl esters," Archives of Biochemistry and Biophysics, vol. 98, no. 2, pp. 253-261, 1962.

[18] O. W. Griffith, "Determination of glutathione and glutathione disulfide using glutathione reductase and 2-vinylpyridine," Analytical Biochemistry, vol. 106, no. 1, pp. 207-212, 1980.

[19] F. Tietze, "Enzymic method for quantitative determination of nanogram amounts of total and oxidized glutathione: applications to mammalian blood and other tissues," Analytical Biochemistry, vol. 27, no. 3, pp. 502-522, 1969.

[20] B. Huang, P. R. Krafft, Q. Ma et al., "Fibroblast growth factors preserve blood-brain barrier integrity through RhoA inhibition after intracerebral hemorrhage in mice," Neurobiology of Disease, vol. 46, no. 1, pp. 204-214, 2012.

[21] Q. Ma, A. Manaenko, N. H. Khatibi, W. Chen, J. H. Zhang, and J. Tang, "Vascular adhesion protein-1 inhibition provides antiinflammatory protection after an intracerebral hemorrhagic stroke in mice," Journal of Cerebral Blood Flow \& Metabolism, vol. 31, no. 3, pp. 881-893, 2011.

[22] Y. Wang, X. Wang, L. Zhang, and R. Zhang, "Alleviation of Acute Lung Injury in Rats with Sepsis by Resveratrol via the Phosphatidylinositol 3-Kinase/Nuclear Factor-Erythroid 2 Related Factor 2/Heme Oxygenase-1 (PI3K/Nrf2/HO-1) Pathway," Medical Science Monitor, vol. 24, pp. 3604-3611, 2018.

[23] J. Tang, J. Liu, C. Zhou et al., "MMP-9 deficiency enhances collagenase-induced intracerebral hemorrhage and brain injury in mutant mice," Journal of Cerebral Blood Flow \& Metabolism, vol. 24, no. 10, pp. 1133-1145, 2004.

[24] H.-J. Lin, C.-C. Hsu, C.-C. Chio et al., "Gamma-Secretase Inhibitors Attenuate Neurotrauma and Neurogenic Acute Lung Injury in Rats by Rescuing the Accumulation of Hypertrophic Microglia," Cellular Physiology and Biochemistry, vol. 44, no. 5, pp. 1726-1740, 2018.

[25] R. M. Leach, P. J. Rees, and P. Wilmshurst, "ABC of oxygen: hyperbaric oxygen therapy," British Medical Journal, vol. 317, no. 7166, pp. 1140-1143, 1998.

[26] B. Basnyat, "High altitude cerebral and pulmonary edema," Travel Medicine and Infectious Disease, vol. 3, no. 4, pp. 199-211, 2005.

[27] M. Gómez-Choco, C. Doucerain, X. Urra, A. M. Planas, and Á. Chamorro, "Presence of heat shock protein 70 in secondary lymphoid tissue correlates with stroke prognosis," Journal of Neuroimmunology, vol. 270, no. 1-2, pp. 67-74, 2014.

[28] J.-H. Zhao, X.-L. Meng, J. Zhang, Y.-L. Li, Y.-J. Li, and Z.-M. Fan, "Oxygen glucose deprivation post-conditioning protects cortical neurons against oxygen-glucose deprivation injury: Role of HSP70 and inhibition of apoptosis," Journal of Huazhong University of Science and Technology (Medical Sciences), vol. 34, no. 1, pp. 18-22, 2014. 
[29] C. Chang, S. Chen, T. Lin et al., "Heat shock protein 70 protects against seizure-induced neuronal cell death in the hippocampus following experimental status epilepticus via inhibition of nuclear factor- $\kappa \mathrm{B}$ activation-induced nitric oxide synthase II expression," Neurobiology of Disease, vol. 62, pp. 241-249, 2014.

[30] G. Dvoriantchikova, A. R. C. Santos, A. M. Saeed, X. Dvoriantchikova, and D. Ivanov, "Putative role of protein kinase $\mathrm{C}$ in neurotoxic inflammation mediated by extracellular heat shock protein 70 after ischemia-reperfusion," Journal of Neuroinflammation, vol. 11, article no. 81, 2014.

[31] B. Liebelt, P. Papapetrou, A. Ali et al., "Exercise preconditioning reduces neuronal apoptosis in stroke by up-regulating heat shock protein-70 (heat shock protein-72) and extracellularsignal-regulated-kinase 1/2," Neuroscience, vol. 166, no. 4, pp. 1091-1100, 2010.

[32] G. A. Matchett, R. D. Martin, and J. H. Zhang, "Hyperbaric oxygen therapy and cerebral ischemia: Neuroprotective mechanisms," Neurological Research, vol. 31, no. 2, pp. 114-121, 2009.

[33] S. F. Rodrigues and D. N. Granger, "Blood cells and endothelial barrier function," Tissue Barriers, vol. 3, no. 1-2, p. e978720, 2015.

[34] O. Benga and V. J. Huber, "Brain water channel proteins in health and disease," Molecular Aspects of Medicine, vol. 33, no. 5-6, pp. 562-578, 2012.

[35] J. Badaut, A. M. Fukuda, A. Jullienne, and K. G. Petry, "Aquaporin and brain diseases," Biochimica et Biophysica Acta (BBA) - General Subjects, vol. 1840, no. 5, pp. 1554-1565, 2014.

[36] X. Liu, J. Yin, Q. Ma et al., "Role of Arcuate Nucleus in the Regulation of Feeding Behavior in the Process of Altitude Acclimatization in Rats," High Altitude Medicine \& Biology, vol. 18, no. 3, pp. 234-241, 2017.

[37] S. B. Singh, A. Sharma, K. N. Sharma, and W. Selvamurthy, "Effect of high-altitude hypoxia on feeding responses and hedonic matrix in rats," Journal of Applied Physiology, vol. 80, no. 4, pp. 1133-1137, 1996.

[38] N. Nunn, M. Womack, C. Dart, and R. Barrett-Jolley, "Function and pharmacology of spinally-projecting sympathetic preautonomic neurones in the paraventricular nucleus of the hypothalamus," Current Neuropharmacology, vol. 9, no. 2, pp. 262-277, 2011. 


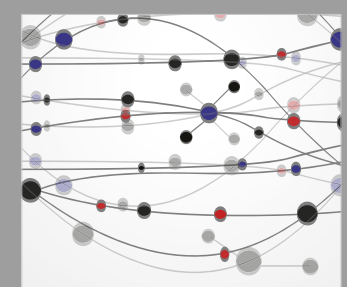

The Scientific World Journal
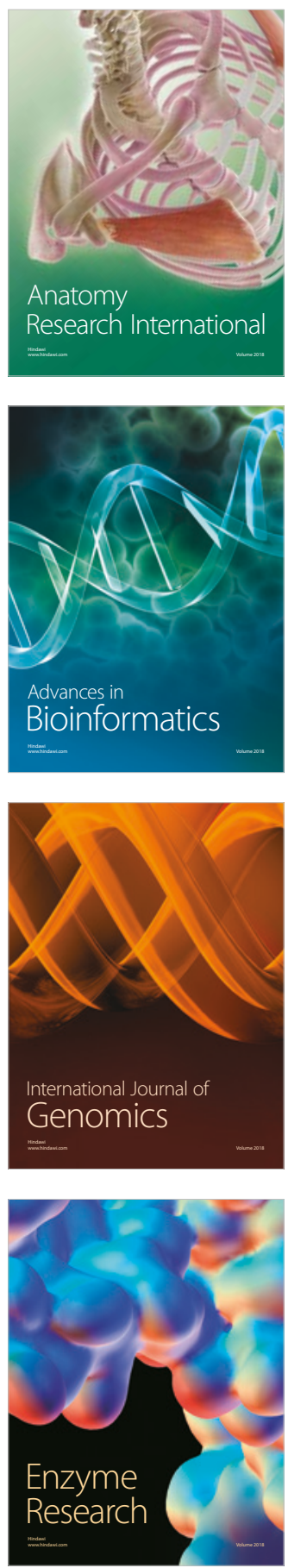
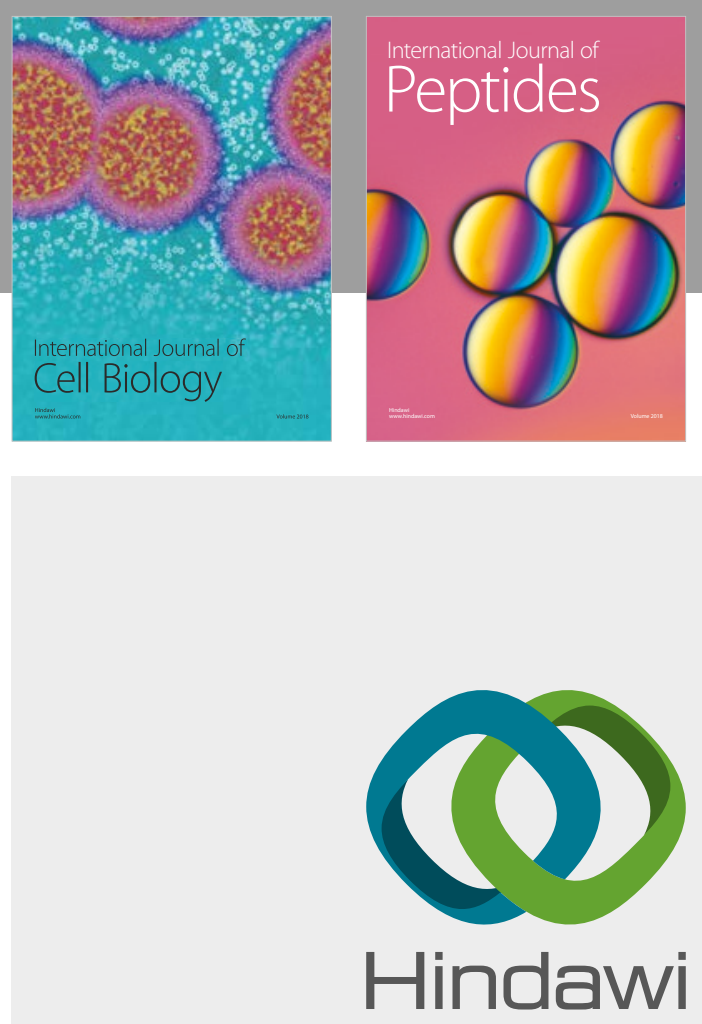

Submit your manuscripts at

www.hindawi.com
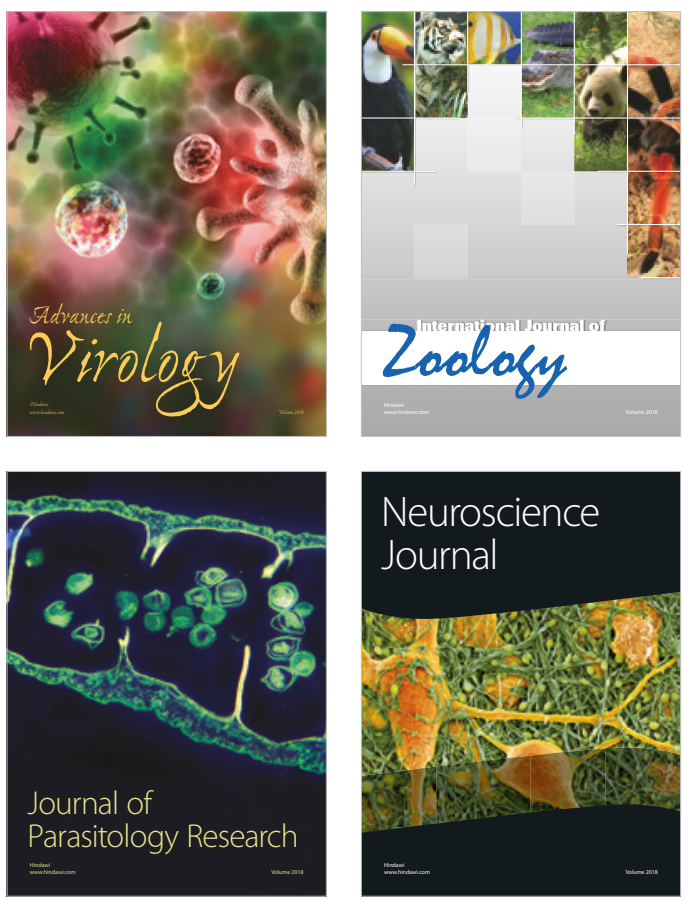
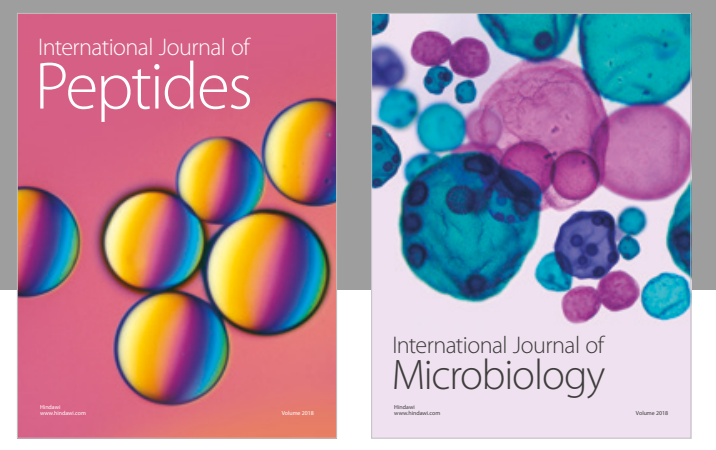

nternational Journal of Microbiology
Journal of
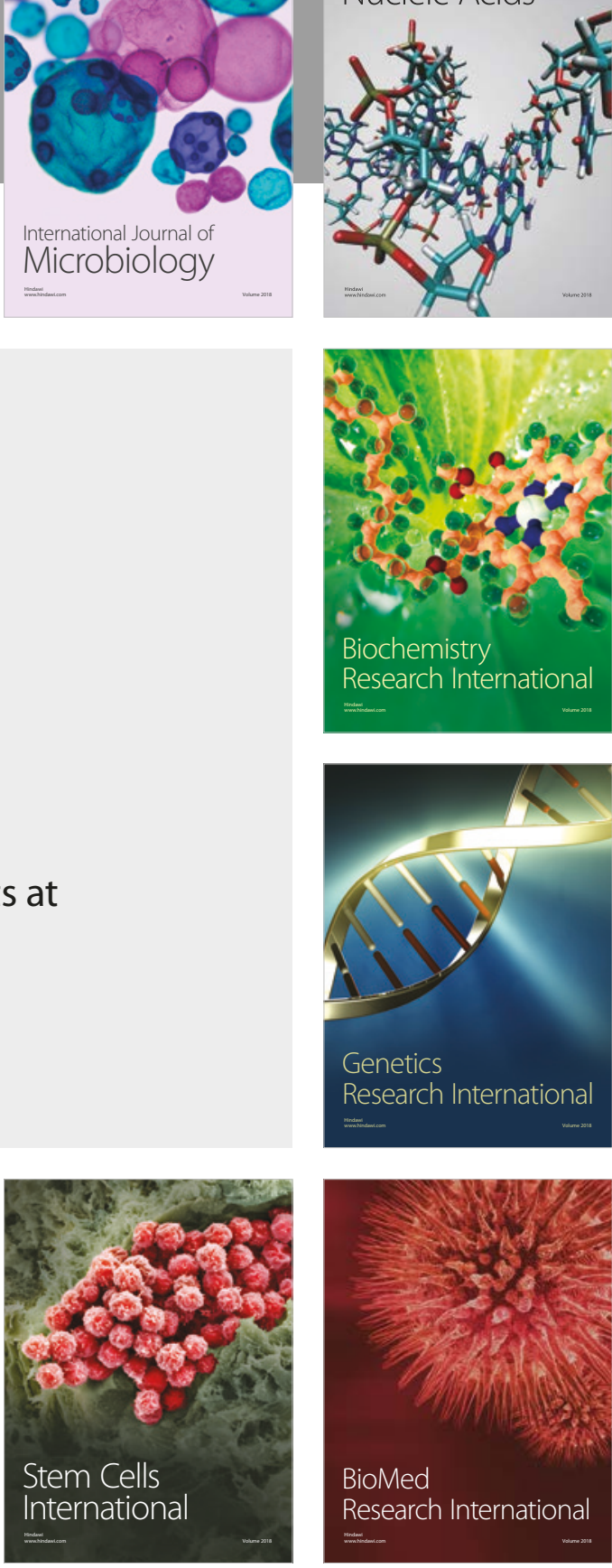
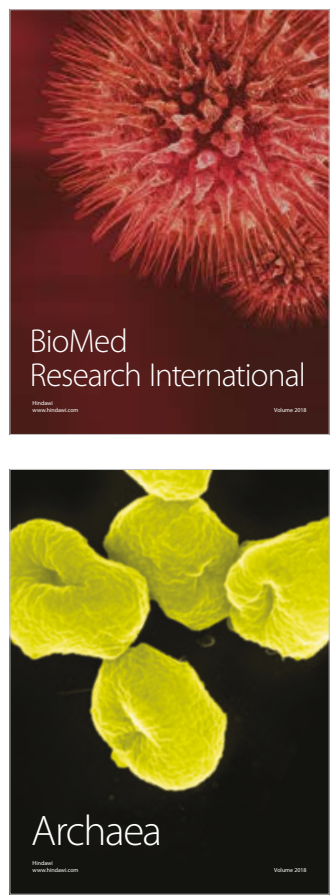